УдК : 321.01

\title{
ПОЛІТИЧНІ УЯВЛЕННЯ НАСЕЛЕННЯ УКРАЇНСЬКИХ ЗЕМЕЛЬ ПРО МІЖНАРОДНІ ВІДНОСИНИ (1950-1960)
}

\section{Хуторянський Михайло Володимирович}

начальник групи по роботі з особовим складом, Київський факультет Національної академії

Національної гвардії Украӥни,

м. Київ, Україна

ORCID: 0000-0003-2310-0592

hutikus87@gmail.com
Надіслано:

11.02.2020

Рецензовано:

10.03.2020

Прийнято:

25.03.2020

Досліджується стан політичних уявлень населення УРСР в умовах переходу тоталітарного та авторитарного режимів у 1950-60-х рр. Звертається увага на тенденції формування політичних настроїв стосовно загострення міжнародної обстановки і перспектив початку нової світової війни. Можливість початку бойових дій у 1950-60-х рр. широко обговорювалася практично всіма верствами радянського суспільства. Цьому сприяли повідомлення у радянських засобах масової інформації. Уявлення про способи ведення війни із досить слабким розумінням природи ядерної війни та розвитку стратегічних носіїв ядерної зброї орієнтувало людей на уявлення про майбутню війну як сутичку, насамперед, сухопутних армій. Обговорення міжнародних відносин в українському суспільстві на поч. 50-х pp. ХX ст. відбувалося, як правило, у зв'язку із визначенням їх впливу на можливість поновлення бойових дій у світовому масштабі. Архівні документи дозволяють стверджувати, що гонка озброєнь, участь у якій СРСР подавалася винятково як засіб протистояти агресивним діям західних країн, не завжди із розумінням сприймалася населенням. Одночасно й наростав страх перед майбутньою війною через пересторогу втрати благ мирного життя. Загалом посилення гонки озброєнь із перспективою нової світової війни не викликало захоплення у більшості населення. Прагнення до збереження мирного життя домінувало серед політичних настроїв населення України.

Ключові слова: міжнародні відносини; політичні уявлення; УРСР; Хрущов; Сталін; війна; СРСР; США; Карибська криза. 
Khutorianskyi Mykhailo, Head of the Personnel Team, Kyiv Faculty of National Academy of National Guard of Ukraine, Kyiv, Ukraine

The International Relations Political Perceptions of the Population of the Ukrainian Lands (1950-1960)

The article examines the state of the political views of the USSR population in the transition of the totalitarian and authoritarian regimes in 1950-1960's. The research attention is drawn to trends in the formation of political attitudes regarding the aggravation of the international situation and prospects for the beginning of a new world war. The possibility of the hostilities outbreak in 1950-1960's has been widely discussed by almost all strata of the Soviet society. This contributed to the reports in the Soviet media. Ideas about the methods of warfare with a very weak understanding of the nuclear war nature and the development of the nuclear weapons strategic carriers focused the people on the view about the future war as a battle primarily of land armies. In the early 1950's, the discussion of international relations in the Ukrainian society occurred, as a rule, in connection with the determination of their influence on possibility of hostilities resumption in the world. Archival documents indicate that the population did not always perceive the arms race, in which the Soviet Union supplied solely as a means to resist the aggressive actions of the Western countries. At the same time, the fear of a future war grew due to the warning of losing the benefits of a peaceful life. The overall strengthening of the arms race with the prospect of a new world war was not delighted in the absolute majority of the population. The desire to preserve the peaceful life dominated the political moods of the Ukrainian population.

Key words: international relations; political representation; the Ukrainian Soviet Socialist Republic; Khrushchev; Stalin; war; the Union of Soviet Socialist Republics; the USA, the Cuban crisis.

Хуторянский Михаил Владимирович, начальник группы по работе с личным составом, Киевский факультет Национальной академии национальной гвардии Украины, г. Киев, Украина

Политические представления населения украинских земель о международных отношениях (1950-1960)

Исследуется состояние политических представлений населения УССР в условиях перехода тоталитарного и авторитарного режимов в 1950-60-х гг. Обращается внимание на тенденции формирования политических настроений относительно обострения международной обстановки и перспектив начала новой мировой войны. Возможность начала боевых действий в 1950-60-х гг. широко обсуждалась практически всеми слоями советского общества. Этому способствовали сообщения в советских средствах массовой информации. Представление о способах ведения войны с достаточно слабым пониманием 
природы ядерной войны и развития стратегических носителей ядерного оружия ориентировало людей на представление о предстоящей войне как схватку в первую очередь сухопутных армий. Обсуждение международных отношений в украинском обществе в начале 50-х гг. происходило, как правило, в связи с определением их влияния на возможность возобновления боевых действий в мировом масштабе. Архивные документы позволяют утверждать, что гонка вооружений, участие в которой СССР подавалась исключительно как средство противостоять агрессивным действиям западных стран, не всегда с пониманием воспринималась населением. Одновременно и нарастал страх перед будущей войной из-за боязни потери благ мирной жизни. В общем усиления гонки вооружений с перспективой новой мировой войны не вызвало восторга у большинства населения. Стремление к сохранению мирной жизни доминировало среди политических настроений населения Украины.

Ключевые слова: международные отношения; политические представления; УССР; Хрущев; Сталин; война; СССР; США; Карибский кризис.

\section{Вступ}

Політичні уявлення населення будь-якої держави формуються у внутрішньодержавних політичних умовах і тому завжди залежать від внутрішньої політики правлячої еліти та існуючого державного політичного режиму. Їх розвиток і характер завжди є достатньо складним для вивчення, особливо ж це стосується тоталітарних та авторитарних режимів, у період існування яких інформація завжди є малодоступною. Особливий же інтерес у цій ситуації викликають політичні уявлення населення щодо міжнародних відносин, оскільки вони $\epsilon$ результатом цілеспрямованої інформаційної політики. Вивчення таких уявлень цілком можна здійснювати на прикладі населення УРСР як складової частини СРСР.

\section{Аналіз останніх досліджень і публікацій}

Уявлення населення УРСР щодо міжнародних відносин в умовах тоталітарного та авторитарного режимів 1950-60-х рр. фактично не досліджувалися. Саме тому основна маса інформації нами залучена із архівних документів. Однак, слід відзначити, що на настрої населення повоєнного періоду в УРСР як наукову проблему звертали увагу в різні роки пострадянського періоду такі вчені як Ю. Шаповал, В. Кононенко,
П. Когут,
О. Малярчук,
М. Герасимова,
А. Бобровський,
I. Романюк, О. Прохоренко,Н. Хоменко, Л. Місінкевич та ін.

\section{Формулювання мети і завдань статті}

Основною метою даної статті є спроба розглянути політичні погляди населення УРСР щодо міжнародних відносин у період зміни внутрішньої 
політичної ситуації та переходу від тоталітарного до авторитарного режиму в рамках СРСР упродовж 1950-1960-х рр.

\section{Виклад основного матеріалу дослідження}

Політичні настрої населення УРСР 1950 - поч. 1960-х рр. формувалися під впливом ряду політичних, економічних та соціальних чинників внутрішньої та зовнішньої політики, серед яких можна виділити загострення міжнародних відносин у рамках холодної війни, завершення процесу відбудови народного господарства та суцільної колективізації на території західноукраїнських областей, продовження репресивної політики із придушенням основних вогнищ опору воїнів УПА. У цей час фактично оформилися політичні настрої громадян України щодо реалізації радянською владою їхніх уявлень про життя після завершення війни.

Доступні джерела дозволяють скласти уявлення про тенденції формування політичних настроїв жителів УРСР стосовно загострення міжнародної обстановки і перспектив початку нової світової війни. Можливість початку бойових дій на рубежі 1950-хрр. широко обговорювалася практично всіма верствами радянського суспільства. Цьому сприяли повідомлення у радянських засобах масової інформації, спрямування пропагандистської кампанії проти українських повстанців.

Занепокоєння людей можливістю початку третьої світової війни підтверджується матеріалами спецповідомлень про настрої населення, які надсилалися відповідальними працівниками до ЦК КП(б)У. Так, у спецповідомленні про реагування населення м. Львів на події внутрішнього та зовнішнього порядку від 8 лютого 1951 р. заступника начальника управління МДБ Львівської обл. Данилова викладено найбільш характерні висловлювання, зафіксовані довіреними особами органів держбезпеки. Наприклад, доцент Львівського політехнічного інституту В. С. Ракіта вказував: «Ми стоїмо на порозі війни із Америкою. Катастрофа ось-ось відбудеться. А ми начебто свідомо йдемо на це і свідомо провокуємо війну. Я не певен, що ми самі перші не почнемо їі. Європа шалено озброюється. Ми також». Науковий співробітник бібліотеки при Львівському філіалі АН УРСР Павловський сказав: «Ситуація складається так, що війна довго не примусить чекати. Йде шалена гонка озброєнь з тієї і з іншої сторони, свого роду змагання, хто швидше і більше зробить - ми чи американці. Правда, у них немає людей, але за хліб і гроші вони знайдуть і людей». Архітектор облпроєкту, місцевий українець, Н. В. Микула відзначив: «Війна невідворотна і буде розв’язана нами на Заході. Радянському Союзу потрібна німецька промисловість, оскільки своя не забезпечує зростаючих потреб техніки. Якщо Америка не зможе дати відсіч, коли СРСР почне прибирати до рук Західну Німеччину, то пізніше їй важко буде боротися із Радянським Союзом» (Tsentralnyi Derzhavnyi Arkhiv..., case 786, 
sheet 11). Студент Львівського університету Лупак, місцевий українець, сказав: «Обстановка напружена, війна може початися і перекинутися на Захід, доля місцевих людей у зв'язку з цим дуже сумна, вони не впевнені у завтрашньому дні» (Tsentralnyi Derzhavnyi Arkhiv..., case 786, sheet 14).

Водночас відзначалися й інші оцінки перспектив початку світової війни. Викладач Львівського сільськогосподарського інституту М. Ф. Листавничий, уродженець Києва, у 1951 р. стверджував: «Війна не скоро буде, оскільки Америка не має доброї сухопутної армії, що стосується Англії, Франції та інших держав, то вони будуть підтримувати Америку лише на словах, а на ділі будуть втілювати у життя іншу лінію, вигідну їм 3 метою звільнення від американського впливу. Навіть Японія не захоче активно допомагати Америці, оскільки вона ще пам'ятає жахи атомної бомби, скинутої Америкою у минулій війні»(Tsentralnyi Derzhavnyi Arkhiv..., case 786, sheet 9-10).

Бачення про способи ведення війни із досить слабким розумінням природи ядерної війни та розвитку стратегічних носіїв ядерної зброї орієнтувало людей на уявлення про майбутню війну як сутичку у першу чергу сухопутних армій. А тому вважалося, що війна може розпочатися на західних кордонах СРСР. Це робило обговорення можливості початку бойових дій актуальним, передусім, для населення західноукраїнських земель. у той же час стурбованість загостренням міжнародної обстановки фіксувалася і серед населення східноукраїнських областей. Мешканці промислових районів, розуміючи, що у випадку початку бойових дій удар ворога може бути спрямований проти них, висловлювали стурбованість у зв'язку із можливістю початку війни. У протоколі звітно-виборчих зборів парторганізації управління МДБ по Сталінській області від 7 січня 1950 p. вказувалося на складність міжнародної обстановки. Тут висловлювалося занепокоєння, що такий важливий промисловий район як Донбас може стати мішенню для ворожих ударів(Tsentralnyi Derzhavnyi Arkhiv..., case388, sheet42). А вже у квітні 1950 р. на закритих партійних зборах партійної організації МВС УРСР стверджувалося про зростання занепокоєності людей можливим початком бойових дій, що не завжди позитивно сприймалося у зв'язку із свіжістю вражень про жахи минулої війни.

Варто підкреслити, що обговорення міжнародних відносин в українському суспільстві на поч. 50-х рр. ХХ ст. відбувалося, як правило, узв'язку із визначенням їх впливу на можливість поновлення бойових дій у світовому масштабі. Архівні документи дозволяють стверджувати, що гонка озброєнь, участь у якій СРСР подавалася винятково як засіб протистояти агресивним діям західних країн, не завжди із розумінням сприймалася населенням УРСР. наприклад, працівник облторгу м. Львів Щербаков вказував у 1951 р.: «Нам швидше війну забезпечать, аніж переоцінку і зниження цін. 
Наш уряд зараз збирає буквально всі копійки на озброєння країни, навіть на військових накладено податок». Продавець магазину по вул. Шпитальній 8 м. Львів Райбах, місцевий єврей, оцінюючи постанову Ради Міністрів про прибутковий податок, як про ознаку війни, заявив: «Напевне у кишені радянського уряду не густо, якщо добралися вже до своєї єдиної опори - армії» (Tsentralnyi Derzhavnyi Arkhiv ..., case 786, sheet 12).

Перспективи зростання впливу комуністичної ідеології у світі також не отримали однозначної оцінки жителів республіки. Так, касир обласної типографії Ф.Ф.Шлезак, поляк, підкреслив: «Якби не Англія, ми, поляки, жили б також у своїй державі, як і перед війною. Я дуже хотів би, щоб Англія отримала такий самий урок, як і Гітлер. І це може відбутися, якщо вона й надалі буде вести політику підбурення однієї держави проти іншої, як вона робить це до останнього дня. У силу цієї політики Англії доведеться випробувати на собі долю Польщі, Німеччини, Чехословаччини та ін. країн. Комуністи підберуться і зроблять в Англії радянську владу» (Tsentralnyi Derzhavnyi Arkhiv..., case 786, sheet 12 ).

Певною мірою увагу українців привертали події війни у Кореї на поч. 50-х рp. ХХ ст. Напад Північної Кореї на Південну був сприйнятий світовою громадськістю як акт агресії. Більш того, його розцінили як початок комуністичної експансії у Азії, як акцію СРСР і Китаю із захоплення континенту (Mlechin, 1990, p. 14). Показово, що подібні оцінки цього протистояння були розповсюджені й на території західноукраїнських областей. У якості показових у «секретних папках» ЦК КП/б/У наведено кілька висловлювань. Так, наприклад, студент 1 курсу Львівського політехнічного інституту Н. В. Хабер, місцевий українець,із приводу подій у Кореї у лютому 1951 р. заявив: «Я не задоволений тим, що китайські добровольці надають допомогу Корейській народно-демократичній армії, а американці ведуть себе пасивно. Якщо так буде продовжуватися, то комуністи завоюють увесь світ» (Tsentralnyi Derzhavnyi Arkhiv..., case 786, sheet 13). Не варто забувати, що одним із результатів корейської війни стало створення радіостанцій «Свобода» і «Вільна Європа», чиє антирадянське спрямування слугувало процесу формування відповідних політичних настроїв.

Водночас у радянському суспільстві, в тому числі й в Україні, події Корейської війни 1950-1953 рр. сприймалися в основному відповідно до настанов радянської пропаганди. Солдати-українці, як i iнші бійці, які воювали у Кореї в основному вважали, що виконують інтернаціональний обов'язок, захищаючи братський корейський народ. Підкоряючись присязі, вони виконували відповідні накази (Mlechin, 1990, p. 15).

Загалом події в Кореї не були у центрі обговорення населенням України політичних подій. Війна відбувалася далеко від кордонів республіки, 
i зацікавлення в основному викликав факт протистояння СРСР i США, оскільки про подробиці бойових дій пересічні громадяни практично не мали інформації. Прагнення мирного життя було сильнішим за примарні вигоди перемоги комунізму у всьому світі та зростання впливу СРСР на міжнародній арені завдяки збільшенню могутності армії.

Згідно з результатами аналізу листів громадян України, надісланих до редакції газети «Правда» у 1951 р., найбільше хвилювала населення саме перспектива участі у війні, яку сприймали 3 великими пересторогами, вважаючи, що ніякі блага, отримані у результаті бойових дій, не зможуть замінити втрати рідних чи близьких людей (Tsentralnyi Derzhavnyi Arkhiv..., case 2079, sheet 5). Страх перед можливим початком бойових дій змушував людей замислюватися над переїздом до більш віддалених східноукраїнських земель, які у випадку війни потрапили б під удар пізніше, або могли б взагалі уникнути його.

Варто відзначити й наростання страху перед майбутньою війною через пересторогу втрати благ мирного життя. Так, асистент кафедри Львівського ветеринарного інституту, місцевий українець В. І. Саєвич говорив: «Думати про майбутню війну мені просто страшно. Краще як тепер мені не доведеться жити. Ви думаєте, що я міг би працювати у інституті асистентом при іншій владі? Ніколи я б не працював, не допустили б мене. Звичайно, $\epsilon$ такі люди, яким не подобається радянська влада, не подобається й те, що ми, західники, чесно працюємо, вони чекають моменту, щоб нас за це помститися, але вони дочекаються, вони лише у період німецької окупації називали себе «героями» (Tsentralnyi Derzhavnyi Arkhiv..., case 786, sheet 9). Існували і протилежні судження. Наприклад, відповідно до матеріалів спецповідомлень, студент 4 курсу політехнічного інституту м. Львів I. О. Мармуш, місцевий українець, у лютому 1951 р. наголосив: «У випадку війни необхідно сховатися з метою ухилення від служби в армії і можливого арешту, оскільки перед початком війни всіх підозрілих осіб будуть заарештовувати. Добре було б після початку війни зв'язатися із підпіллям ОУН у Львові або виїхати у свій район і створити організацію ОУН для ведення боротьби проти радянської влади» (Tsentralnyi Derzhavnyi Arkhiv..., case 786, sheet 13). Як відзначалося у документах радянських спецслужб, що надавалися для ознайомлення працівникам ЦК КП/б/У, особи, які співробітничали з УПА, виявляли надію на початок війни між СРСР та США, в результаті якої могла б бути утворена Українська держава (Tsentralnyi Derzhavnyi Arkhiv..., case 1718, sheet 1-7).

На противагу цьому співробітники партійних та радянських органів, а також працівники спецслужб всіляко намагалися сформувати у суспільстві негативне ставлення до українських повстанців, звинувачуючи їх 
успівробітництві із німцями під час Другої світової війни. Всіляко формувалося у суспільстві негативне ставлення до осіб, які співробітничали із німцями, навіть, якщо воно було вимушеним. Причому у випадку виявлення таких фактів, навіть якщо після звільнення особи служили у Червоній Армії, мали поранення і бойові нагороди, військові трибунали, як правило, обирали міру покарання у вигляді 10 років позбавлення волі із конфіскацією майна та ураженням у правах. Причому така міра покарання у діяльності трибуналів була найменшою, а факти їі призначення перевірялися вищими інстанціями (Tsentralnyi Derzhavnyi Arkhiv..., case 2078, sheet 88-93).

Загалом, посилення гонки озброєнь із перспективою нової світової війни не викликало захоплення у більшості населення. Причому, як видно із архівних матеріалів, в основному негативне сприйняття продовження бойових дій у будь-якій формі із використанням будь-яких гасел (як-то боротьба за панування комунізму у всьому світі або відновлення Української державності) було характерним для мешканців всіх регіонів республіки та представників основних соціальних груп, чиї висловлювання були представлені на сторінках довідок «про політичні реагування» населення. Прагнення до збереження мирного життя домінувало серед політичних настроїв населення України.

Як свідчать архівні матеріали колишніх «секретних папок» ЦК КПУкраїни, пересічні громадяни республіки у більшості випадків виявляли стурбованість про свою і долю країни в цілому у зв'язку зі смертю «вождя народів». На відкритих засіданнях та мітингах, у зв'язку зі смертю Й.В.Сталіна, висловлювали почуття глибокої втрати. Особливе занепокоєння викликав страх перед можливим початком війни. Так, заступник начальника матеріальної служби управління південно-західної залізниці Ємельянов вказав: «Радянський народ і Комуністична партія зазнали великої втрати, коли така складна міжнародна обстановка, коли у Америці прийшов до влади фашистський уряд, який робить все для розв'язування війни на сході. Тому у цей період потрібен був товариш Сталін, який зміг би прийняти вірне рішення. Але раз так вийшло треба не піддаватися на різного роду провокації»(Tsentralnyi Derzhavnyi Arkhiv..., case 2743, sheet 5).

Страх перед війною у зв'язку зі зневірою у можливості вищого партійного керівництвапісля смерті Й.В. Сталіна відвернути початок бойових дій залишався у центрі висловлювань з приводу смерті «вождя». Дружина столяра мостозагону № 2 Т. Ригалова підкреслила: «Тепер напевне буде війна, нехай краще віддадуть країну, аніж доведеться пережити війну». Робітник станції Пінізевичі Зінченко 6 березня сказав: «Немає Сталіна, важко буде нашій країні у теперішній міжнародній обстановці. Війна буде скоро, кожен день ешелони з танками йдуть на Захід, схоже, що готується те, що було у 1941 p.» (Tsentralnyi Derzhavnyi Arkhiv..., case 2743, sheet 7). 
Фактично, у вищих ешелонах влади в СРСР розгорнулася боротьба «за думки та настрої людей». Усвідомлюючи існування соціального попиту на відмову від масових репресій і курсу на нову світову війну частина радянських лідерів включилася у формування оновленої системи цінностей суспільства. Нове керівництво СРСР відмовилося від сталінських планів підготовки до Третьої світової війни, розуміючи, що економічний потенціал і технічні можливості ї̈ ведення не забезпечать перемоги Радянської країни. Тому вже 16 березня 1953 р. Маленков публічно заявив, що СРСР і США можуть домовитися 3 будь-якої міжнародної проблеми. Фактично відбувалося формування полярного світу із пріоритетом «американського» та «радянського» проєктів розподілу світової арени на сфери впливу, але антиамериканська істерія у радянській пресі почала потроху спадати (Zubov, 2009, p. 292).

Але критика окремих радянських діячів у часи Й.В.Сталіна та М.С.Хрущова (та й Л. І.Брежнєва) не повинна була підривати основ радянського ладу. А отже, новій владі кожного разу потрібно було закріпити у суспільній свідомості уявлення про себе як про реформатора, який забезпечив полегшення життя громадян. Для М. С. Хрущова у 1953-1955 рр. такими діями стало нагнітання міжнародної напруженості із рекламою успіхів СРСР у гонці озброєнь, реформи оподаткування сільгоспвиробників, «замкнення на собі» процесу реабілітації із затушовуванням ролі Л.Берія у його початку, гучне святкування «возз'єднання України з Росією», передача Криму до складу УРСР, а пізніше - слава борця зі злочинами сталінізму.

Як було зазначено вище, оцінка перспектив участі Радянської країни у світовій війні була досить розповсюдженою серед спектра проблем, що найбільше хвилювали радянських людей. Побоювання втягнення Радянської країни у війну були поширеними серед усіх верств населення. Причому перспектива поразки у війні майже проти всього світу викликала масу критичних зауважень на адресу тих, кого вважали «паліями війни». I якщо у офіційних документах мова йшла у цьому зв'язку, насамперед, про західних політиків, то у повідомленнях радянських спецслужб вказувалося, що громадяни нерідко критикували радянських керівників за недалекоглядну політику, яка могла б призвести до початку бойових дій.

У зв'язку із цим успіхи СРСР у гонці озброєнь використовувалися правлячою верхівкою для формування вигідних для себе політичних настроїв громадян. Важливою рисою у цій справі стала розробка і успішне випробовування водневої бомби, яка стала розглядатися як вагомий засіб у «стримані західних агресорів», а отже, забезпечувала ілюзію перемоги СРСР у термоядерній війні. Ілюзорність перемоги полягала у масштабності ядерної 
катастрофи у зв'язку із початком збройного протистояння. Але факт успішного випробовування нової зброї подавався як засіб захисту інтересів СРСР.

Повідомлення про успішне випробовування водневої бомби було здійснене Г. Маленковим, а тому реакція населення на цю подію у документах подавалася як «реагування населення на промову Г. Маленкова». У містах і районах республіки для забезпечення потрібного правлячій верхівці реагування було здійснено масштабну підготовчу роботу по проведенню зібрань трудящих, присвячених обговоренню рішень п’ятої сесії Верховної Ради СРСР і промови Г. Маленкова. Для надання допомоги партійним організаціям у розгортанні роз'яснювальної роботи, підготовці і проведенні зборів трудящих обкоми партії виділяли групи керівних працівників, які направлялися до відповідних районів республіки. А вже райкоми партії послали до сіл актив по 50-60 осіб. (Tsentralnyi Derzhavnyi Arkhiv..., case 2776, sheet 6). Це, безперечно, сприяло формуванню громадської думки. У документах ЦК КП України вказувалося, що з особливою радістю було сприйнято повідомлення Маленкова про те, що США не $є$ монополістами у виробництві водневої бомби. Схвалення викликало виділення мільярда карбованців на відновлення господарства Кореї. Для висловлювань з питання про міжнародне становище СРСР була характерною спокійна впевненість у ефективності Радянського уряду (Tsentralnyi Derzhavnyi Arkhiv..., case 2776, sheet 7).

Сталевар Київського заводу «Більшовик» Щука сказав: «характеризуючи міжнародну обстановку і зовнішню політику Радянського Союзу, товариш Маленков відповів на всі важливі питання. Він повністю викрив політику «холодної війни» американських імперіалістів. I якщо американська «кума» почне танцювати не 3 тієї ноги, ми зможемо їі приборкати». У бесіді, яку проводив парторг шахти «Рудуч» тресту Горлівськвугілля вибійник Пахомов заявив: «Хай не думають американці, що вони залякають весь радянський народ. Весь наш народ із радістю слухав заяву голови Уряду, що така «втіха», як воднева бомба, також вибита з їхніх рук». Вибійник шахти № 4-2-біс м. Кадієвка Єлецький говорив: «від всієї душі ми підтримуємо рішення уряду про виділення мільярда карбованців на відновлення зруйнованого господарства Кореї». Майстер Ужгородського деревообробного комбінату Коньч висловився так: «Мені дуже сподобалося, що американці не є монополістами на водневу бомбу. 3 виступу Георгія Максимільяновича видно, що ми сильні і у народному господарстві, і у обороні країни» (Tsentralnyi Derzhavnyi Arkhiv..., case2776, sheet 1-2).

Уроки карибської кризи були враховані обома сторонами. Уявляється, що як М.Хрущов, так i Дж.Кеннеді усвідомили небезпеку політики балансування на межі війни і необхідність компромісів. У всякому разі, з боку СРСР погроз застосування ядерної зброї у локальних конфліктах більше 
не висловлювалося. Виступаючи на сесії Верховної Ради СРСР 12 грудня 1962 р., М.С. Хрущов визначив політику мирного співіснування як рішення спірних питань між державами без війни, мирним шляхом. Він зазначив, що досвід карибського конфлікту «змусить багатьох людей змінити свої погляди на розвиток міжнародного становища і свою оцінку співвідношення сил на міжнародній арені. Вони більш реально будуть представляти зараз небезпека ядерної катастрофи».

Не відмовляючись від підтримки революційних сил і рухів «третього світу», КПРС стала виявляти велику обережність у зовнішній політиці. У ході такої бурхливої полеміки в комуністичному русі з питання про методи протидії агресивним акціям імперіалізму ЦК КПРС, явно враховуючи уроки міжнародних криз, висловився проти методу «боротьби вістрям проти вістря». Прихильники подібних дій, відзначав ЦК КПРС у 1963 р., очевидно, вважають, що Радянський Союз повинен відповідати провокаціями на провокації, повинен прийняти виклик імперіалізму на змагання в авантюризмі і агресивності, тобто у змаганні не за забезпечення миру, а в розв'язуванні війни. 5 серпня 1963 р. у Москві був підписаний «Договір про заборону випробувань ядерної зброї в атмосфері, космічному просторі й під водою».

Протистояння між СРСР та США було перенесено у сферу локальних воєн по всьому світу, але загроза взаємного зіткнення була певною мірою усунута. Результатом цього конфлікту стала різка зміна політичних настроїв населення передусім в СРСР (у тому числі й на території УРСР) та США. Більшість людей, усвідомивши важливість збереження миру в умовах існування зброї масового знищення, здатної знищити Землю, стали активно брати участь у русі за мир. Кубинська ракетна криза відкрила очі М.Хрущову на небезпеку неконтрольованої гонки озброєнь (Fursenko, Naftali, 1999, pp. 519-520).

Набув досить значного поширення Пагвоський рух за мир, в якому брали участь передусім відомі вчені, що застерігали проти ядерної війни. Поширення руху за мир відбувалося в умовах, коли технічні засоби зв'язку між СРСР та США не дозволяли здійснювати прямий зв'язок між найвищими керівниками обох країн. А тому частина повідомлень передавалася по радіо. Це зробило протистояння відкритим для обговорення громадськістю. У своїх спогадах учасники протистояння - вихідці з України - вказували на величезну занепокоєність можливістю початку бойових дій. Водночас вони наголошували, що виконали б відповідний наказ, оскільки вірили у комуністичні ідеали та залишалися вірними присязі.

Водночас частина військових вважала, що М. Хрущов зазнав поразки у протистоянні із США і засуджувала його. За деякими даними це навіть стало однією 3 причин усунення Хрущова 3 посади у 1964 р. Але подібні 
Міжнародні відносини: теоретико-практичні аспекти

Випуск 5 (2020)

ISSN (print) 2616-745X; ISSN (online) 2616-7794

висловлювання про поразку Дж.Кеннеді існували і у середовищі Збройних сил США.

\section{Висновки}

Таким чином, ми можемо стверджувати, що уявлення населення УРСР складалися в рамках парадигми протистояння країн соціалістичного табору на чолі з СРСР та капіталістичних країн. При цьому, основне питання, яке насправді переважно турбувало населення - це реальність третьої світової війни і застосування ядерної зброї. При цьому для людей практично були байдужі проблеми міжнародних економічних, культурних чи інших процесів. Цілий ряд подій міжнародного життя та їх перебіг, зокрема події в часи Карибської кризи, не були невідомі для населення УРСР. Водночас, слід відзначити, що міжнародний матеріал мав, все ж таки, обмежений характер інформаційного поширення. Міжнародна інформація на теренах УРСР у постсталінський період стала більш доступною, хоча й достатньо серйозно фільтрувалася партійною номенклатурою та органами влади.

\section{References:}

1. Fursenko, A., Naftali, T. (1999). Adskaya igra. Sekretnaya istoriya Karibskogo krizisa 1958-1964 [Infernal game. The Secret History of the Caribbean Crisis 19581964.] Moscow.

2. Zubov, A. B. ed. (2009). Istoriya Rossii. XX vek. 1939-2007 [Russian history. XX century. 1939-2007]. Moscow: AST, Astrel', OGIZ.

3. Mlechin, L. (1990). Koreya: taynaya voyna [Korea: The Secret War]. Sovershenno sekretno [Topsecret], no. 10, pp. 14-15.

4. Tsentralnyi Derzhavnyi Arkhiv Hromadskykh Obiednan v Ukraini [Central State Archives of Public Organizations of Ukraine], Fund 1, Description 24.

(C) Хуторянський М. В., 2020 